\title{
WHY IS FISCAL POLICY OFTEN \\ PROCYCLICAL?
}

\author{
Alberto Alesina \\ Harvard University
}

Filipe R. Campante

John F. Kennedy School of Government, Harvard University

\section{Guido Tabellini \\ IGIER Bocconi}

\begin{abstract}
Fiscal policy is procyclical in many developing countries. We explain this policy failure with a political agency problem. Procyclicality is driven by voters who seek to "starve the Leviathan" to reduce political rents. Voters observe the state of the economy but not the rents appropriated by corrupt governments. When they observe a boom, voters optimally demand more public goods or lower taxes, and this induces a procyclical bias in fiscal policy. The empirical evidence is consistent with this explanation: Procyclicality of fiscal policy is more pronounced in more corrupt democracies. (JEL: E62, D73, D78)
\end{abstract}

\section{Introduction}

Most economists agree with the normative prescription that tax rates and discretionary government spending as a fraction of GDP ought to remain constant over the business cycle. If governments respected these prescriptions, we should observe a countercyclical pattern in fiscal policy. Namely, during a boom, (i) total government spending as a share of GDP should go down because of automatic stabilizers (if discretionary spending remained constant in real terms, the effect would be reinforced); (ii) with constant tax rates and some degree of progressivity, government revenues as a share of GDP should go up (the effect would be reinforced by tax cuts in recessions and tax increases in boom.); (iii) as a result,

The editor in charge of this article was Jordi Gali.

Acknowledgments: We thank Jordi Galí and three anonymous referees for excellent comments. We are also grateful to Robert Barro, Eliana La Ferrara, Paolo Manasse, Roberto Perotti, Kenneth Rogoff, Francesco Trebbi, Aleh Tsivinsky, and participants in a seminar at Harvard for useful suggestions, Ashoka Mody and Diego Saravia for help with part of the data collection, and Davide Cantoni for outstanding research assistantship and comments. We gratefully acknowledge financial support from NSF through a grant from NBER (Alesina) and CIFAR, MIUR, and Bocconi University (Tabellini). E-mail addresses: Alesina: aalesina@harvard.edu; Campante: filipe_campante@harvard.edu; Tabellini: guido.tabellini@unibocconi.it 
budget surpluses as a share of GDP should increase. The opposite should occur in recessions. ${ }^{1}$

In practice, in many developing countries fiscal policy has the opposite properties: it is procyclical. In particular, government spending as a share of GDP goes up during booms and down in recessions, and deficits increase in booms and decrease in recessions. In OECD countries, in contrast, fiscal policy is generally countercyclical. ${ }^{2}$ Gavin and Perotti (1997) were the first to point out that in Latin America fiscal policy is procyclical; then Talvi and Vegh (2005), Catão and Sutton (2002), Manasse (2005), and Kaminski, Reinhart, and Vegh (2004) noted that this is not a Latin American phenomenon only: Procyclicality of fiscal policy is common in many - though not all—developing countries.

Why do many countries follow seemingly sub-optimal procyclical fiscal policies that add to macroeconomic instability? A common answer relies upon the supply of credit. In bad times, many developing countries cannot borrow, or can do so only at very high interest rates, therefore they cannot run deficits and have to cut spending; in booms, they can borrow more easily and choose to do so, increasing public spending (cf. Gavin and Perotti 1997; Catão and Sutton 2002; Riascos and Vegh 2003; Kaminski, Reinhart, and Vegh 2004). ${ }^{3}$

In our view, however, this argument is incomplete, because it begs two critical questions. First, why don't these countries self-insure by accumulating reserves in good times, so that they are less likely to face binding credit constraints in recessions? Second, why would lenders not provide funds to countries, even in recessions, if they were convinced that the borrowing would optimally smooth out the cycle?

To answer both questions one needs to consider the political arena, as others have done and as we do in this paper. In Talvi and Vegh (2005), the presence of surpluses increases the government propensity to spend; the present article and Talvi and Vegh (2005) are complementary because they focus on how a political distortion interacts with different economic structures (in particular with the variability of revenues). In this article, we focus on deriving the political distortion. A different but not mutually exclusive political explanation is the "voracity effect" of Tornell and Lane (1999), Lane and Tornell (1998), and Lane (2003):

1. In light of the careful discussion of Kaminski, Reinhart, and Vegh (2004) we want to be clear regarding our choice of words. We define as countercyclical a policy that follows the tax-smoothing principle of holding constant tax rates and discretionary government spending as a fraction of GDP over the cycle. They define such policy as "acyclical." Both we and they would define as procyclical a policy in which tax rates go down in booms and up in recessions, and spending over GDP goes up in booms. As those authors themselves note, our definition is the most common in the literature.

2. Some countries in both groups have accumulated large amounts of public debt. For a review of models that explain excessive deficits, see Alesina and Perotti (1995) and Persson and Tabellini (2000). On the cyclical properties of fiscal policy in OECD countries, see Galí and Perotti (2003).

3. Riascos and Vegh (2003) provide a formalization of the credit channel, whereas most of the other reports are only empirical. 
When more resources are available (i.e., in booms), the common-pool problem is more severe, and the fight over common resources intensifies, leading to budget deficits. We consider empirically this possibility as well.

In our article, voters face corrupt governments that can appropriate part of tax revenues for unproductive public consumption, namely, political rents. Rents can be thought of as direct appropriation (stealing) of tax revenues by government officials, but also as favors paid to special interests such as public employees or "friends" of the government, often identified along ethnic or religious lines, and so on. Voters can replace a government that abuses its powers, but in equilibrium they generally cannot push rents all the way to zero. This agency problem interacts with lack of information: Voters observe the state of the economy, but they cannot observe government borrowing, at least not at the margin; for instance, the government can accumulate hidden off-balance-sheet liabilities. Hence, when voters see the economy booming, they demand higher utility for themselves (in the form of lower taxes or better public goods), in a way that resembles the "starve the Leviathan" argument. This forces the government to impart a procyclical bias to fiscal policy, and to borrow too much. Thus, procyclical and myopic fiscal policy (i.e., an increase in government spending during booms and excessive government borrowing) arises from voters' demands. But voters do not demand irrational policies: Through a reelection constraint on the government, they obtain a second-best solution to an agency problem in an environment of corruption and imperfect information. Formally, the model extends to a dynamic environment with public debt a model of moral hazard and political accountability originally formulated by Barro (1973) and Ferejohn (1986) and adapted to public finance by Persson and Tabellini (2000). ${ }^{4}$

We then discuss some features of the data. First, we confirm previous evidence on the widespread procyclicality of fiscal policy. Second, we show a positive correlation between procyclicality and measures of corruption: More corrupt countries display a more procyclical fiscal policy. Third, the correlation between corruption and procyclicality is only or mainly present in democracies, confirming the theoretical idea that procyclicality emerges because voters try to hold corrupt governments accountable. Finally, we ask how robust is the correlation between corruption and procyclicality when also taking into account the evidence on borrowing constraints. This is not easy, because more corrupt governments might also face more binding credit constraints. As a result, many of the same variables that influence political corruption are also likely to affect the severity of borrowing constraints-indeed, corruption is highly correlated with credit ratings in the data. (In fact, credit rating agencies may look at corruption as one indicator

4. Note the idea that voters induce debt accumulation to discipline governments that they do not trust is related to Jensen and Meckling (1976). That seminal contribution shows that debt financing (as opposed to external equity financing) can mitigate the agency problem inside the firm. Of course, the mechanism through which this happens in our political context is different. 
of countries' ability to pursue stable macroeconomic policies.) Nevertheless, we present some suggestive evidence that political agency problems in democracies, rather than, or at least in addition to, credit market imperfections, are the underlying cause of procyclical fiscal policy. ${ }^{5}$ Finally, our political agency explanation can coexist with other political distortions, and in particular with the voracity effect. In fact, we present some evidence consistent with this interpretation.

Our idea that political agency can lead to excessive debt accumulation when voters are uninformed also differs from two other political models of government borrowing in the literature. The strategic debt argument (Persson and Svensson 1989; Alesina and Tabellini 1990; Tabellini and Alesina 1990) does not rely on an agency problem: Voters are not uninformed about fiscal policy, and the results are driven by different preferences among political parties or groups of voters alternating in government. In the rational budget cycles literature (Rogoff and Sibert 1988; Rogoff 1990), voters face an adverse selection problem, and this leads to distorted fiscal policy before the election. The assumption about voters' information is similar to ours, but here the incentive problem is one of moral hazard, not adverse selection. Moreover, those papers do not discuss the reaction of economic policy to external shocks, nor do they allow for a state variable like government debt.

The article is organized as follows: In Section 2 we lay out the model; in Section 3 we derive the economic and political equilibrium; Sections 4 and 5 discusses the empirical evidence; and the last section concludes.

\section{The Model}

\subsection{The Economy}

Consider a small open economy with an infinite horizon. The private sector consists of a representative consumer that maximizes the present discounted value of expected utility from private and public consumption:

$$
E \sum_{t=0}^{\infty} \beta^{t}\left[u\left(c_{t}\right)+h\left(g_{t}\right)\right],
$$

where $c_{t}$ and $g_{t}$ denotes private and public consumption respectively in period $t$, $E$ is the expectations operator, and $u(\cdot)$ and $h(\cdot)$ are smooth and strictly concave increasing functions. For simplicity, we neglect the intertemporal choices of the

5. Satyanath and Subramanian (2004) show empirical evidence that democratic failure explains macroeconomic instability. However, they focus on the distinction between democracies versus. nondemocracies, whereas we argue that procyclical fiscal policy stems from the interaction of democratic accountability and political corruption. 
private sector and only focus on its political role of controlling the government agency problem. Thus, we assume that private consumption in each period is just given by endowment income $(y)$ net of taxes $(\tau): c_{t}=y_{t}\left(1-\tau_{t}\right)$. The model is meaningful only if government debt is non-neutral and there is a role for countercyclical fiscal policy, and this is the simplest way to get that property. Income is an i.i.d. random variable, drawn each period from a distribution with bounded support over $[y, \bar{y}]$. All variables are expressed in per capita terms. ${ }^{6}$

Besides spending in "useful" government consumption that provides utility to the consumer, $g_{t}$, the government can also appropriate rents, $r_{t} \geq 0$, that benefit the government but not the consumer. In period $t$ the government can issue public debt, $b_{t+1}$, at a market price $\beta$. Government debt is bought by foreign residents and there is full repayment of debt next period. ${ }^{7}$ Thus, we can write the government budget constraint as

$$
g_{t}+r_{t}+b_{t} \leq \tau_{t} y_{t}+\beta b_{t+1} .
$$

We assume that there is a limit to how much resources a government can appropriate for its own exclusive benefit: $r_{t} \leq q_{t}$. The upper bound $q_{t}$ denotes what the government can steal from the public coffers without ending up in jail. We consider two alternative assumptions about $q_{t}$. In the simplest case, it is a linear and increasing function of current per capita income: $q_{t}=\bar{q}+\rho y_{t}$, $\rho>0$. Thus, as the tax base rises, the government has more opportunities to grab rents. Alternatively, we assume that the upper bound is a decreasing and concave function of public debt outstanding: $q_{t}=Q\left(b_{t}\right)$, with $Q_{b}<0, Q_{b b}<0$. Thus, if the previous legislature accumulated a large amount of government debt, there is less room to steal today. As discussed in the next section, debt is only observed by the public at large in the subsequent period, when it has to be repaid. Thus, this second assumption says that, if the government accumulated large liabilities in the previous legislature, it is under more careful scrutiny today, both from the domestic voters and international organizations, and as a result the upper bound on rents is more severe. As we shall see, the assumption that there is an upper bound on rents plays a role even if this constraint is not binding in equilibrium, because it determines the strength of out-of-equilibrium threats. But the policy response to income shocks is similar irrespective of whether the upper-bound $Q_{t}$ does or does not depend on government debt outstanding.

Finally, we assume that government debt can be issued only up to a maximum amount $\bar{b}$. Up to this amount, debt is always repaid in full and there is no default risk nor any credit market imperfection. This upper limit on government debt

6. Alternative but more complicated assumptions would be to allow the consumer to borrow or lend in an economy with tax distortions, or to model explicitly a liquidity constraint on private consumption.

7. The assumption of a small open economy is appropriate for our empirical work, in which we consider this kind of country. Without default risk there is no risk premium, but in the empirical analysis we allow for the effects of risk premia on government-issued liabilities. 
is low enough (compared to the possible realizations of per capita income), so that the non-negativity constraints on consumption and rents are not violated in equilibrium:

$$
\begin{aligned}
\underline{\mathrm{y}}(1-\rho)-\bar{b} & >\bar{q}>0, \\
\underline{\mathrm{y}}-\bar{b} & >Q(\bar{b})>0 .
\end{aligned}
$$

The left-hand-side inequalities in equations (3) and (4) guarantee that outstanding debt can always be repaid in full when rents are at a maximum, without pushing private or public consumption to zero. The right-hand-side inequality in equation (4) implies that there is always something to steal, even if the upper bound on rents is a decreasing function of debt, and debt is maximal. These assumptions play no role, other than to make sure that the equilibrium does not violate some non-negativity constraints.

In this simple environment, the optimal policy for the voters certainly entails $r_{t}=0$. The optimal debt policy can be characterized by noting that a benevolent social planner in this economy faces exactly the same optimization problem as a consumer with stochastic income and subject to a debt limit. This optimization problem has been analyzed in the literature (cf. Ljungqvist and Sargent 2000, ch. 14). In particular, Aiyagari (1994) has shown that, if income is i.i.d. and the interest rate equals the rate of time discount (as is the case in our model), then asymptotically debt diverges to $-\infty$; that is, the planner accumulates an unbounded quantity of assets. This implies that asymptotically a benevolent government would behave as if the debt limit did not exist, implementing a policy of full smoothing of public and private consumption. While assets remain finite, a benevolent government would still smooth private and public consumption in the face of income shocks, although not fully, provided that the debt limit is not binding in the current period. In particular, unless the debt limit currently binds, a negative income shock would lead to some debt accumulation (asset depletion) and the sum of private and public consumption would fall less than one for one with income. Conversely, a positive income shock would induce a debt reduction (asset accumulation) and only a fraction of the income increase would be spent in the current period. ${ }^{8}$ Also note the asymmetry between positive and negative income shocks: The debt limit can never bind when the economy is hit by a positive income shock, so that debt will always be reduced in this case. A negative income shock instead leads to some debt accumulation only if the debt limit is not currently binding.

8. See Ljungqvist and Sargent (2000, ch. 14) and Aiyagari (1994) for more details. 


\subsection{The Political System}

Elections are held at the end of each period. The incumbent government only cares about grabbing rents for itself. Thus, it maximizes

$$
E \sum_{t=0}^{\infty} \beta^{t} v\left(r_{t}\right)
$$

where it is understood that the government can get rents only while in office (if the incumbent is not reappointed, then future political rents will be enjoyed by another politician in office). The utility function $v(\cdot)$ is smooth, increasing, and strictly concave.

The political environment is adapted from Barro (1973), Ferejohn (1986), and Persson and Tabellini (2000, chapter 4). Specifically, government policy is chosen after the elections, by the incumbent, and there is no commitment to electoral promises. Thus, there is an element of "contract incompleteness" in the political environment, and the government can only be held accountable ex post through backward-looking voting strategies. This accountability is made possible by assuming that, at each election, the incumbent is challenged by an identical opponent, whose role is to provide an alternative. Voters coordinate the optimal voting strategy that minimizes their loss of welfare from this agency problem. Relative to the models of Barro, Ferejohn, and Persson and Tabellini, we have added government debt. This makes the model truly dynamic, whereas the previous literature on political agency had static economic environments.

Voters observe private and public consumption, their income, and how much they are paying in taxes. But they do not observe government rents, nor how much government debt is being accumulated (or decumulated) in the current period. This is equivalent to saying that the government can incur off-balancesheet liabilities with which to pay for hidden rents. The size of these liabilities and of total government spending inclusive of rents in the current period only becomes known to the voters after the elections. This assumption is consistent with the vast literature that has emphasized the size and significance of creative accounting and lack of transparency of the budget especially in developing countries; it has the same flavor of the information assumptions of the literature on rational political business and budget cycles. ${ }^{9}$ Note how an ex post "discovery" of large government

9. See in particular Von Hagen and Harden (1994), Alesina and Perotti (1995), Milesi Ferretti (2003), among others, on the role of lack of transparency in the budget process, and Rogoff (1990), Rogoff and Sibert (1988), and Persson and Tabellini (2000) for rational political cycles. Note that there is an asymmetry: While voters do not observe $b_{t+1}$ until period $t+1$, foreign lenders do not lend to the government past the point $\bar{b}$; hence international financial markets have better information about the debt policy compared to national voters. Qualitatively, this assumption is not implausible, 
liabilities may trigger more control over the government and therefore make it more difficult for the government to appropriate rents in the future, which is one of the cases we examine subsequently.

Thus, the sequence of events is as follows: (i) At the start of each period, before government policy is chosen, voters observe their income before taxes in the current periods, $y_{t}$, and debt outstanding, $b_{t}$; they select a reservation level of current period utility, $x_{t}$, and promise reelection to the incumbent conditional on attaining at least that level of current utility (i.e., if $\left.u\left(c_{t}\right)+h\left(g_{t}\right) \geq x_{t}\right)$. (ii) The government observes the reservation utility demanded by voters as well as their current income, and sets policy for the current period, namely rents $\left(r_{t}\right)$ and government debt $\left(b_{t+1}\right)$. (iii) Voters observe their utility from private and public consumption and vote according to their promise. This sequence of events is repeated in each period.

An equilibrium is a reservation level of utility that is optimal for the voters in the current period, given the initial conditions and taking into account subsequent equilibrium outcomes, and a policy that is optimal for the government, given the voting strategy and subsequent equilibrium outcomes. Note that this definition of sequential equilibrium rules out pre-commitment by the voters to a sequence of voting rules. Voters can punish the government for bad behavior during the current legislature. But we do not allow voters to punish the government for the policy chosen before the previous election, once they discover how much public debt was accumulated during the previous legislature. In other words, we restrict attention to Markov-perfect equilibria. Because the government is fully informed and there is no asymmetric information, rational voters can fully predict government policy, even if they do not observe it. Hence, in equilibrium no government change occurs and the incumbent is always re-elected, although the threat of out of equilibrium events is a major determinant of the voters' and of the government's decisions.

\section{Equilibrium Policies}

In this section, we characterize the equilibrium and then we discuss its properties. Because it is simpler, we emphasize the case in which the upper bound on rents is a linear function of income irrespective of public debt outstanding: $q_{t}=\bar{q}+\rho y_{t}$. The appendix describes the equilibrium under the alternative assumption that $q_{t}=Q\left(b_{t}\right)$.

although here for simplicity it is formulated in a very stark form: Voters are totally ignorant, whereas foreign investors are perfectly informed. As we shall see, however, the upper bound $\bar{b}$ plays no role in the case in which the ceiling on rents is a function of debt outstanding: $q_{t}=Q\left(b_{t}\right)$. 
Suppose first that the incumbent chooses to forgo reelection. In this case, he will certainly grab as many rents as possible, and obtain utility $v\left(q_{t}\right)=$ $v\left(\bar{q}+\rho y_{t}\right) .^{10}$

Next, suppose that the incumbent government seeks to please the voters. Let $W(b, y, x)$ be the incumbent's maximal utility in this case, given current income $y$, debt outstanding $b$, and the reservation utility demanded by voters, $x$. Let a primed variable denote next period values. Then $W(b, y, x)$ is defined by

$$
W(b, y, x)=\max _{\tau, g, r, b^{\prime}}\left[v(r)+\beta E V\left(b^{\prime}, y^{\prime}\right)\right],
$$

subject to the government budget constraint (2), to the upper bounds on rents and government debt, and to the reelection constraint: $u[y(1-\tau)]+h(g) \geq x$. The function $V(\cdot)$ is the equilibrium value of reappointment for the incumbent, in the future state $\left(b^{\prime}, y^{\prime}\right)$. The expectations operator is over the random variable $y^{\prime}$.

The incumbent can always choose to forgo reelection. Hence, voters cannot push government utility below the threshold $v(\bar{q}+\rho y$ ) (what he can achieve by grabbing maximal rents once). In other words, for any values of $b$ and $y$, voters' demands have to satisfy the following incentive constraint:

$$
W(b, y, x) \geq v(\bar{q}+\rho y) .
$$

Clearly, it is optimal for the voters to demand private consumption up to the point where incentive constraint (6) holds as equality. Not doing that would simply enable the government to grab more rents for itself, without increasing voters' utility in current and future periods. Hence, equilibrium demands by the voters, $x^{*}$, are a function $x^{*}=X(b, y)$, defined implicitly by the condition

$$
W\left(b, y, x^{*}\right)=v(\bar{q}+\rho y) .
$$

We can then define the equilibrium value of reappointment, namely the function $V(b, y)$ introduced previously, as

$$
V(b, y)=W\left(b, y, x^{*}\right)=v(\bar{q}+\rho y),
$$

where the last equality follows by condition (7).

Because definition (8) must hold for any values of $b$ and $y$, it must also hold in all future periods. Thus, $V\left(b^{\prime}, y^{\prime}\right)=v\left(\bar{q}+\rho y^{\prime}\right)$ for all possible values of $y^{\prime}$ and $b^{\prime}$. Based on equations (5) and (8), equilibrium rents in the current period, $r^{*}$, are then implicitly defined by the following condition:

$$
v\left(r^{*}\right)+\beta E v\left(\bar{q}+\rho y^{\prime}\right)=v(\bar{q}+\rho y) .
$$

10. Under our assumptions, government debt policy in this out-of-equilibrium outcome is not well defined (in the sense that the government is indifferent about $b_{t+1}$ ). But we don't need to specify the out-of-equilibrium debt to determine the equilibrium outcome, so we leave it at that. 
The left-hand side of condition (9) is the incumbent's utility if he pleases the voters, given the equilibrium continuation value of being reappointed tomorrow. The right-hand side is his utility if he steals as much as possible today, but is then thrown out of office. In equilibrium, the incumbent must be indifferent between these two options. ${ }^{11}$ Equation (9) can be easily solved to obtain equilibrium rents:

$$
r^{*}=R(y) \equiv v^{-1}\left[v(\bar{q}+\rho y)-\beta E v\left(\bar{q}+\rho y^{\prime}\right)\right] .
$$

It remains to determine the other fiscal policy variables for a government seeking re-appointment. Using the previous notation, this is the solution to the following optimization problem:

$$
\max _{\tau, g, b^{\prime}}\left[v\left(\tau y-g+\beta b^{\prime}-b\right)+\beta E V\left(b^{\prime}, y^{\prime}\right)\right],
$$

subject to $b^{\prime} \leq \bar{b}$ and to the reelection constraint, $u[y(1-\tau)]+h(g) \geq x^{*}$. The expression inside the parentheses corresponds to rents in the current period. The last term is the expected equilibrium continuation value (i.e., what the incumbent expects to get from next period onwards if he is re-appointed).

By this argument, $E V\left(b^{\prime}, y^{\prime}\right)=v(\bar{q}+\rho y)$ for any value of $b^{\prime}$. This means that, from the perspective of a government seeking reappointment, issuing public debt in the current period entails no future costs. The costs are fully borne by the consumers. But by assumption, consumers do not observe government debt until next period. Hence, the incumbent can pocket the proceeds from issuing government debt in the form of higher rents. Indeed, the optimal debt policy that solves equation (11) is to always borrow as much as possible: $b^{*}=\bar{b}$.

Finally, public consumption and tax rates are pinned down by the optimality condition (subscripts denote derivatives)

$$
u_{c}\left[\left(1-\tau^{*}\right) y\right]=h_{g}\left(g^{*}\right),
$$

together with the government budget constraint (2). Intuitively, a government seeking reelection will allocate available resources between private and public consumption to please the voters in the most efficient way possible, consistent with its desire to grab as many rents as the voters allow it to.

We summarize all this in the following:

PROPOSITION 1. Suppose that the upper bound on rents is a linear function of income, $q_{t}=\bar{q}+\rho y$. Then the equilibrium stochastic steady state has

$$
\begin{aligned}
& r^{*}=R(y) \equiv v^{-1}\left[v(\bar{q}+\rho y)-\beta E v\left(\bar{q}+\rho y^{\prime}\right)\right], \\
& b^{*}=\bar{b} .
\end{aligned}
$$

11. Implicitly, we are thus assuming equilibrium rents to be always positive, for all realization of $y$. This assumption can be easily relaxed with slightly more complicated notation. 
Moreover, $g^{*}=G(y)$ and $\tau^{*}=T(y)$ are jointly defined by

$$
\begin{aligned}
g^{*}+r^{*}+\bar{b}(1-\beta) & =\tau^{*} y, \\
h_{g}\left(g^{*}\right) & =u_{c}\left[y\left(1-\tau^{*}\right)\right] .
\end{aligned}
$$

The steady state is reached after one period.

Note that although in the case presented here the government goes immediately to the borrowing constraint, this is an artifact of the simplicity of our specification, and it is not critical. The Appendix solves the case in which the upper bound on rents depends on debt outstanding: $q_{t}=Q\left(b_{t}\right)$. The solution procedure is very similar, the only difference being that issuing government debt now is costly for the government, because it reduces the value of its out-ofequilibrium threat next period. As a result, equilibrium debt is now at an interior optimum lower than the upper bound $\bar{b}$, and the steady state is reached gradually rather than at once. But throughout the adjustment to the steady state, and once the steady state is reached, public consumption and the tax rate move with income as described herein, except that now equilibrium rents are not affected by income shocks. Equilibrium debt also does not respond to income shocks. Hence, the cyclical properties of fiscal policy in this more general version of the model are equivalent to those described in Proposition 1 (see the subsequent discussion for more detail).

\subsection{Discussion}

By assumption, income $y$ is an i.i.d. random variable. Thus, income shocks are temporary and they can be interpreted as business fluctuations. This section discusses how fiscal policy responds to these income shocks.

Differentiating the expression for equilibrium rents in Proposition 1, we obtain

$$
R_{y}=\frac{\rho v_{r}(\bar{q}+\rho y)}{v_{r}\left(r^{*}\right)}>0 .
$$

Thus, equilibrium rents are procyclical. What is the interpretation? As income increases, the incumbent temptation to grab maximal rents and forgo reelection also increases. Optimizing voters must thus accept an increase in equilibrium rents. The size of the increases in rents depends on the parameter $\rho$ (which captures the extent to which the upper bound of rents varies with income) and on the curvature of the government preferences. Procyclicality of rents is more pronounced the higher $\rho$ is (i.e., the more the ceiling on rents increases with income), and the less the marginal utility of rents declines as they increase (i.e., the smaller $v_{r r}$ is in absolute value). 
Next, applying the implicit function theorem to the expressions for $G(y)$ and $T(y)$ in Proposition 1, we obtain

$$
\begin{aligned}
T_{y} & =\frac{(1-\tau) u_{c c}+\left(R_{y}-\tau\right) h_{g g}}{\left(u_{c c}+h_{g g}\right) y} \lessgtr 0, \\
G_{y} & =\frac{u_{c c}\left(1-R_{y}\right)}{u_{c c}+h_{g g}} \lessgtr 0 .
\end{aligned}
$$

The signs of $T_{y}$ and $G_{y}$ are ambiguous. To see why the tax rate can move either way with income, suppose that $R_{y}=\tau<1$ and consider a positive income shock. In this special case, if the tax rate were to remain constant, all the additional tax revenues would be fully absorbed by rents, leaving public consumption unchanged. But this cannot be optimal, because part of the positive income shock would also increase private consumption (because $\tau<1$ ). To maintain equality in the marginal utilities of private and public consumption, the government is then forced to raise the tax rate with income. This holds a fortiori if $R_{y}>\tau$. As $R_{y}$ falls below $\tau$, however, equality in the marginal utilities of private and public consumption may require tax rates to go down. Thus, a procyclical tax rate is more likely the more procyclical rents are, and the more concave the utility of private consumption is, relative to that of public consumption (i.e., the larger $h_{g g}$ is relative to $u_{c c}$ in absolute value, so that public consumption behaves more like a luxury good relative to private consumption).

Equations (13) and (14) also imply that

$$
G_{y}+R_{y}=\frac{u_{c c}+R_{y} h_{g g}}{u_{c c}+h_{g g}}>0 .
$$

Therefore, total public outlays net of interest payments (the sum of productive government consumption and rents) always increase with income. As a percentage of GDP, productive government spending plus rents can go up or down depending on parameter values, but it is more likely to go up the higher $R_{y}$ is, that is, the more procyclical rents are.

Under the assumptions of Proposition 2 in the Appendix (i.e., if $q_{t}=Q\left(b_{t}\right)$ ), equilibrium rents do not react to income shocks, while the expressions for $G_{y}$ and $T_{y}$ are the same, except that now $R_{y}=0$. Thus, the increase in income is entirely captured by the consumer with a combination of more public and private consumption.

Finally, note that, as long as $R_{y}<1$, the sum of private and public consumption (and hence voters' utility) always increases with income; and in the case in which $R_{y}=0$ (as in Proposition 2 or if $\rho=0$ ), total consumption increases with income one for one. Government debt, instead, is not affected at all by income 
shocks. Thus, positive income shocks are not saved through the government budget to bring about higher utility for tomorrow; and negative income shocks do not lead to more government borrowing.

These implications of the model contrast with the socially optimal policy. As discussed in the previous section, in this same model economy a benevolent government would accumulate unbounded assets (rather than incur debt) and asymptotically achieve full consumption smoothing. More importantly, a benevolent government would always respond to a positive income shock with an increase in the budget surplus. And a negative income shock would be met with a fall in the surplus, unless the government is up against a debt limit. In our political equilibrium, instead, the budget surplus does not respond to income shocks at all. These different debt policies imply that the response of private and public consumption to income shocks would be smoother under a benevolent government than in the political equilibrium described previously.

Summarizing, compared to the socially optimal policy, the equilibrium response of fiscal policy to a positive income shock in the model is distorted in the following way: (i) the budget surplus increases less than socially optimal (it does not increase at all here, while it increases under a benevolent government); and (ii) total government consumption and wasteful government spending (political rents) increase more than socially optimal. We cannot unambiguously compare the response of the equilibrium tax rate to the social optimum, however. A benevolent government would hold the tax rate roughly constant in the face of income shocks (the tax rate could actually go up or down depending on the relative concavity of the utility from private versus public consumption). Likewise, in the equilibrium described herein, the tax rate can go up or down in response to a positive income shock, depending on how responsive are equilibrium rents to income shocks. Thus, although for different reasons, the response of the tax rate to income shocks is ambiguous both in this equilibrium and under a benevolent government. A negative income shock would imply correspondingly different responses of fiscal policy in our equilibrium versus the social optimum (with signs reversed), except if the social planner was up against a debt limit, in which case a negative income shock would induce similar responses in the social optimum and in our political equilibrium.

Thus in our model the policy response to income shocks is distorted irrespective of whether the government is up against its debt ceiling or not (i.e., under both Propositions 1 and 2, and also outside of the steady state). This failure to smooth income shocks with fiscal policy is due to an agency problem, not to a credit market imperfection. The intuition is straightforward: consumers do not observe debt accumulation. They also know that they cannot trust the government. Thus, when they see better macroeconomic conditions, they demand higher utility for themselves. If they did not do that, the government would simply appropriate more rents, and they would not receive any higher consumption 
in the future anyway. The converse happens when income is seen to go down.

Finally, note that in the model the degree of "corruption" is a zero-one variable: either the government can appropriate rents, in which case fiscal policy is procyclical, or it cannot, in which case fiscal policy is socially optimal. This stark contrast comes from the strong assumptions on government preferences. We also solved a two-period version of this model with a relative weight capturing how much the government cares about rents relative to consumer welfare. In such a model, the degree of procyclicality is a function of the weight given to consumer welfare: the more government cares about rents, the larger is the reaction of private utility to income shocks (i.e., the more procyclical is fiscal policy, in the sense described previously).

\section{Evidence}

\subsection{Empirical Strategy}

The previous sections outlined two alternative explanations of procyclicality in fiscal policy. The most common explanation maintains that policy is set by a benevolent government and attributes procyclicality to a binding credit constraint. This implies that fiscal policy should be procyclical only in recessions, when the government would like to borrow but is prevented from issuing more debt. The alternative hypothesis explains procyclical fiscal policy as the result of a political agency problem. This type of procyclicality arises both in booms and recessions, but should be more prevalent in countries where political corruption is widespread and the government is somewhat accountable to the voters. We now discuss the evidence in light of these alternative explanations.

Our measure of cyclicality in fiscal policy follows Catão and Sutton (2002), who in turn adapt Gavin and Perotti's (1997) specification. We measure procyclicality in country $i$ by the coefficient $\beta_{i}$ from the following panel regression $(t$ subscripts denote years):

$$
\Delta F_{i t}=\beta_{i} \text { OUTPUT_GAP } P_{i t}+\gamma X_{i t}+\lambda F_{i t-1}+\alpha_{i}+v_{t}+\varepsilon_{i t},
$$

where $F_{i t}$ is a fiscal policy indicator (government surplus, or public spending), OUTPUT_GAP ${ }_{i t}$ is a measure of the business cycle, $X_{i t}$ is a vector of other controls, and $\alpha_{i}, v_{t}, \varepsilon_{i t}$ are unobserved error terms. All these variables are defined subsequently. A problem with the approach in much of the existing literature on the procyclicality of fiscal policy concerns the estimation of the parameter of interest, $\beta_{i}$. If income itself reacts to fiscal policy, as in a standard neo-Keynesian model, a simple OLS regression of fiscal policy on the output gap would lead to a biased estimate that might capture the size of the fiscal multiplier rather than the 
policy reaction function. Here we cope with this problem as suggested in recent work by Jaimovich and Panizza (2007) and by Galí and Perotti (2003) —namely, we estimate $\beta_{i}$ by instrumental variables, instrumenting the output gap of country $i$ with the output gap of the region of country $i$ (excluding country $i$ itself). The definition of the regions is standard. ${ }^{12}$

Because we are testing for procyclicality of fiscal policy, we need to observe at least two or three cycles in each country. Thus we include a country in our sample only if we have at least 16 years of data. Our results are not overly sensitive to the choice of this number: In general, the larger the cutoff for inclusion is, the stronger the results are, which is comforting because countries with very few observations probably add only noise to the estimates. In addition, very small countries are exposed to very large shocks, and this makes them more difficult to compare to larger countries. For this reason, we limit our sample to countries larger than 1 million inhabitants. These two criteria and availability of data leave us with an unbalanced panel of 83 countries over the period 1960 to 2003.

We proceed in two ways. Our preferred method is to estimate equation (15) in a panel of yearly data, pooling all countries together to gain efficiency. Country fixed effects are generally included, so the estimates only reflect within-country variation. The political agency model suggests that procyclicality is more likely in countries where corruption is widespread. Hence, we interact the variable OUTPUT_GAP with a measure of the control of corruption. If the interaction term suggests that fiscal policy is more procyclical in more corrupt countries, we interpret this as evidence in favor of the political agency model (the sign of $\beta_{i}$ consistent with a procyclical policy response depends on the precise definition of the fiscal policy variable $F$ ).

As an alternative, we also estimate equation (15) on each country separately, and then regress the estimated $\beta_{i}$ coefficients on a measure of corruption and other controls in a cross-country regression. The lagged dependent variable is always included, both in the panel and when estimating equation (15) on each country separately.

\subsection{Data}

Fiscal policy. The model has clear predictions about two fiscal policy variables: the budget surplus and total government spending net of transfers (the variable $g+r$ in the model). Both variables are predicted to be more procyclical under

12. We use the regions as defined by the World Bank: High-Income OECD countries, High-Income non-OECD countries, East Asia and Pacific, Eastern Europe and Central Asia, Latin America and Caribbean, Middle East and North Africa, South Asia, and Sub-Saharan Africa. The region's output is measured in purchasing power parity (PPP)-adjusted terms, in order to avoid fluctuations induced by exchange-rate volatility. 
a corrupt government accountable to the voters than under a benevolent social planner. (Clearly, this comparative prediction carries over once both variables are scaled to GDP.) In other words, we are not interested in whether a specific fiscal policy instrument reacts positively or negatively to the business cycle, but rather in an interaction effect, namely, how government corruption influences the extent of procyclicality. From this perspective, both the surplus and total government spending net of transfers, both scaled to GDP, are equally valid policy indicators to test the model predictions. We neglect the average tax rate, $\tau$, because the model has no clear-cut predictions on how corruption influences this variable. Nevertheless, we have also run regressions where the dependent variable is the average tax rate, and we comment on these results verbally, without displaying them. In the same spirit, we also comment on the results for total government spending, inclusive of transfers (although the model has no prediction for this variable).

The budget surplus refers to the central government, and the source is the International Monetary Fund's International Financial Statistics (IFS). Total government spending net of transfers is measured by government consumption from the World Development Indicators (WDI). It is well known that the quality of the data on the composition of government spending is very poor for developing countries, however, so government consumption is likely to be measured with much greater error than the fiscal surplus. For this reason, the discussion of the results below gives more emphasis to the fiscal surplus than to government consumption.

Income shocks. The variable OUTPUT_GAP is defined as the log deviation of GDP from its Hodrick-Prescott trend. ${ }^{\overline{13}}$ We have also run regressions using GDP growth instead of output gap. The results are broadly consistent with what we present herein, stronger for some specifications and weaker for others. Also, developing countries are likely to be exposed to more volatile economic shocks, and this may make it more difficult to run a countercyclical fiscal policy. To cope with this difficulty, we follow Catão and Sutton (2002) and Gavin and Perotti (1997), and include in all regressions a measure of terms of trade shocks, defined as the log deviation from a Hodrick-Prescott-filtered series of the terms of trade $\left(T O T_{-} G A P\right)$. We weigh this variable with the degree of openness of the country, measured by exports plus imports over GDP. The source for the GDP, openness, and terms of trade series is the WDI.

Control of corruption. To measure the degree of corruption, we use the Control_of_Corruption index from Kaufman, Kraay, and Mastruzzi's (2006) aggregate governance indicators, which aggregates several scores and ratings

13. We set the smoothness parameter of the Hodrick-Prescott filter equal to 6.25, following Ravn and Uhlig's (2002) recommendation for annual data. 
from different sources on a scale of -2.5 to 2.5 . This index is decreasing in the amount of corruption and is available for 1996, 1998, 2000, and 2002-2005. Throughout, we take the average of the available years. These years do not match the extent of our sample and this, unfortunately, is a drawback that we share with many papers that use these data. The justification for this shortcut is that corruption is a variable that does not change quickly over time, and cross-country comparisons remain relatively stable. We also checked our result using other widely used measures of corruption, from Transparency International (available from 1996 onward) and from the International Country Risk Guide (ICRG) (from 1985 onward), and the results are similar.

Democracy. To capture how democratic a country is, we rely on the variable Polity2, which subtracts the country's score in an "Autocracy" index from its score in a "Democracy" index (resulting in a range from -10 to 10), from the Polity IV Project database. We then define the dummy variable Democracy as equal to 1 if Polity 2 is strictly positive and zero otherwise. In some specifications, we also use the continuous variable Polity2. In the cross-country regressions, we average the variables Democracy and Polity 2 over the sample used to compute the fiscal policy measure, but in the panel regressions these two variables vary over time and refer to the relevant year.

Per capita income. To allow for differences in the level of economic development, in the cross-country regressions we control for real per capita income; we measure it as real GDP per capita in international prices (PPP adjusted) in the first year of the sample over which the measure of procyclicality of fiscal policy is computed for each country. The source is the WDI. This variable is called Initial GDP (per capita). In the panel regressions, per capita income is omitted, but differences in the level of economic development are captured by the country fixed effects.

Borrowing constraints. As others have noted (e.g., Gavin and Perotti 1997), procyclical fiscal policy may also result from tight credit constraints. We make use of two variables to proxy for the degree of financial constraints facing a country's government. One of them is an average of the existing sample of ratings attributed by Standard \& Poor's to a country's long-term foreign-denominated sovereign debt ( $S \& P$ Rating) ${ }^{14}$ We interpret this average as an inverse measure

14. Adapting Cantor and Packer's (1996) approach, we attribute numbers from 0 to 6 to S\&P's letter-based system: C (default or selective default); B (high-risk obligations); BB (likely to fulfill obligations, ongoing uncertainty); BBB (adequate payment capacity); A (strong payment capacity); AA (high quality); AAA (highest quality). Countries rated at BBB or better are said to have "investment-grade" ratings. Because changes in ratings occur at irregular intervals, we computed the average by weighing a given rating by the first integer greater than the number of years over which it was kept. 
TABLE 1. Cyclicality of the budget surplus: OECD versus non-OECD (dependent variable: $\triangle$ CGSurplus).

\begin{tabular}{lccccc}
\hline & \multicolumn{2}{c}{ OECD samples } & & \multicolumn{2}{c}{ Non-OECD samples } \\
\cline { 2 - 3 } \cline { 5 - 6 } & $(1)$ & $(2)$ & & $(3)$ & $(4)$ \\
\hline Output_Gap & 0.492 & 0.549 & & -0.074 & -0.018 \\
& $(0.160)^{* * *}$ & $(0.163)^{* * *}$ & & $(0.154)$ & $(0.149)$ \\
Country FE & No & Yes & No & Yes \\
Observations & 528 & 528 & & 1199 & 1199 \\
$R^{2}$ & 0.121 & 0.158 & & 0.187 & 0.261 \\
\hline
\end{tabular}

Notes: IV regression, "Rest of Region" output gap as instrument; robust standard errors in parentheses. Sample limited to countries with at least 1 million inhabitants (average over the sample) and more than 15 data points.

Controls: TOT_Gap, CGSurplus $(t-1)$.

${ }^{*}$ Significant at $10 \%$; ${ }^{* *}$ significant at $5 \%$; ${ }^{* * *}$ significant at $1 \%$.

of the degree of financial constraints facing a country's government. The other variable is the logarithm of the spread (in basis points) of a country's sovereign debt over U.S. Treasury bonds at the time of issuance (Spread), which comes from Capital Data Bondware and SDC Platinum. ${ }^{15}$ This constitutes a direct measure of financial constraints. Both variables are available for a limited number of countries (70 and 47, respectively) and only over the most recent period (for most countries the sample starts in the 1990s). To avoid losing too many observations, here we always take the average of these variables over the available time period. Thus, like for the measure of corruption, the variables measuring borrowing constraints do not vary over time and their average is not taken over the sample used to compute the fiscal policy variable.

\section{Results}

\subsection{Procyclicality}

We start by studying the cyclical response of the budget surplus and total government spending in two samples of countries. Table 1 displays the $\beta$ coefficient in equation (15), estimated separately in two panels for OECD and non-OECD countries, respectively (OECD membership is as defined in 1975). Country-fixed effects are included in even-numbered columns, not in odd columns, as indicated.

The $\beta$ coefficients are positive in OECD countries and insignificantly different from zero in developing countries. Thus, fiscal policy is countercyclical only in developed countries, a result in line with previous empirical studies (cf.

15. Similarly to the case of ratings, the issuance of new debt occurs at irregular intervals. We thus use a similar weighting system to compute the average spread, taking into account the length of the period between emissions. 
TABLE 2. Cyclicality of the government consumption: OECD versus non-OECD (dependent variable: $\Delta$ GovCons).

\begin{tabular}{lccccc}
\hline & \multicolumn{2}{c}{ OECD sample } & & \multicolumn{2}{c}{ Non-OECD sample } \\
\cline { 2 - 3 } \cline { 5 - 6 } & $(1)$ & $(2)$ & & $(3)$ & $(4)$ \\
\hline Output_Gap & -5.756 & -10.106 & & -2.480 & -3.681 \\
& $(5.056)$ & $(5.073)^{* *}$ & & $(7.960)$ & $(7.789)$ \\
Country FE & No & Yes & No & Yes \\
Observations & 628 & 628 & & 1377 & 1377 \\
$R^{2}$ & 0.028 & 0.136 & & 0.050 & 0.113 \\
\hline
\end{tabular}

Notes: IV regression, "Rest of Region" output gap as instrument; robust standard errors in parentheses. Sample limited to countries with at least 1 million inhabitants (average over the sample) and more than 15 data points.

Controls: TOT_Gap, GovCons $(t-1)$.

${ }^{*}$ Significant at $10 \% ;{ }^{* *}$ significant at $5 \% ;{ }^{* * *}$ significant at $1 \%$.

Kaminski, Reinhart, and Vegh 2004). This is consistent with the predictions of the political agency model: Corruption is much more widespread in developing countries. Indeed, the control of corruption indicator (that varies from -2.5 to $+2.5)$ is 1.7 on average in OECD countries, whereas it is -0.2 in the non-OECD sample. The results are also consistent with a simple credit constraints explanation, however, because credit rationing is likely to be more frequent in non-OECD countries.

Changes in the surplus reflect both changes in spending and revenues. We have investigated these two components separately, and we found that both contribute to a more procyclical fiscal policy in developing countries compared to OECD countries. Of the two, spending shows the clearest pattern (as implied by our model) even though the coefficients on spending are often not significantly different from zero both in OECD countries and developing countries. As already noted, however, the definition of government outlays from standard statistical sources includes spending both on goods and transfers. In the model instead the variable $g$ corresponds to spending on public consumption, whereas transfers are a negative tax. Thus, Table 2 reports the same panel estimation of Table 1, but the dependent variable is government consumption as defined in the WDI. Government consumption in percent of GDP goes down with the output gap in OECD countries (in the regression with country-fixed effects). In developing countries the sign of the coefficient on output gap is essentially zero.

A more careful analysis of spending and tax revenues would require a deeper investigation of elasticity of various components of spending and taxes revenues to the business cycle. ${ }^{16}$ This goes beyond the scope of the present article and would have to rely on scarcely reliable data for developing countries.

16. See Talvi and Vegh (2005) for an insightful discussion of these issues in the politico-economic model described in the Introduction. 
TABLE 3. Pooled sample: Corruption and the cyclicality of the budget surplus in democracies and non-democracies (dependent variable: $\triangle$ CGSurplus).

\begin{tabular}{lccc}
\hline & $(1)$ & $(2)$ & $(3)$ \\
\hline Output_Gap & 0.068 & -0.174 & -0.042 \\
Control_Corruption $\times$ Output_Gap & $(0.131)$ & $(0.220)$ & $(0.154)$ \\
& 0.241 & & \\
Control_Corruption $\times$ Output_Gap $\times$ Democ & $(0.087)^{* * *}$ & & \\
Control_Corruption $\times$ Output_Gap $\times$ NonDemoc & & 0.298 & \\
& & $(0.143)^{* *}$ & \\
Control_Corruption $\times$ Output_Gap $\times$ Polity 2 & -0.034 & \\
& & $(0.167)$ & 0.023 \\
Observations & & & $(0.012)^{* *}$ \\
$R^{2}$ & 1727 & 1694 & 1694 \\
\end{tabular}

Notes: IV regression, "Rest of Region" output gap as instrument; all regressions with country-fixed effects; robust standard errors in parentheses. Sample limited to countries with at least 1 million inhabitants (average over the sample) and more than 15 data points.

Controls: TOT_Gap, CGSurplus $(t-1)$; Columns (2) (resp. (3)) also Democ, Control_Corruption $\times$ Democ, and Output_Gap $\times$ Democ $($ resp. Polity2, Control_Corruption $\times$ Polity2, and Output_Gap $\times$ Polity2).

${ }^{*}$ Significant at $10 \% ;{ }^{* *}$ significant at $5 \% ;{ }^{* * *}$ significant at $1 \%$.

\subsection{Procyclicality and Corruption}

Here we explore the relationship between procyclicality and corruption more systematically, by interacting the output gap with a measure of control of corruption. Consider a positive income shock. As discussed in the previous sections, the socially optimal countercyclical policy entails a rise in the budget surplus and no change (or possibly a small increase) in total government spending. The equilibrium under a corrupt government, instead, has no change in the budget surplus and an increase in total government spending (a procyclical policy). When variables are scaled to GDP, the budget surplus should rise or remain constant in the social optimum, but it unambiguously falls with a corrupt government. Similarly, total government spending in percent of GDP should fall under a benevolent government, and it could rise or remain constant or fall under a corrupt government. ${ }^{17}$ Hence, compared to a benevolent social planner, a corrupt government should display a more procyclical policy response.

Keeping these predictions in mind, let us now look at the evidence. In Table 3 the dependent variable is the surplus in percent of GDP. Two additional regressors (TOT_GAP and the lagged surplus) and country fixed effects are always included but not reported for brevity. Column 1 shows that better control of corruption indeed pushes towards a positive effect of OUTPUT_GAP, corresponding to a

17. If it falls even with the corrupt government it falls less than with a benevolent planner, given the implication on the budget balance discussed previously. 
TABLE 4. Pooled sample: Corruption and the cyclicality of government consumption in democracies and non-democracies (dependent variable: $\Delta$ GovCons).

\begin{tabular}{lccc}
\hline & $(1)$ & $(2)$ & $(3)$ \\
\hline Output_Gap & -4.974 & -22.346 & -1.942 \\
& $(6.649)$ & $(13.646)$ & $(8.411)$ \\
Control_Corruption $\times$ Output_Gap & -5.304 & & \\
Control_Corruption $\times$ Output_Gap $\times$ Democ & $(3.866)$ & -21.326 & \\
& & $(6.238)^{* * *}$ & \\
Control_Corruption $\times$ Output_Gap $\times$ NonDemoc & & 4.75 & \\
Control_Corruption $\times$ Output_Gap $\times$ Polity2 & & $(10.728)$ & -1.634 \\
& & & $(0.548)^{* * *}$ \\
Observations & 2005 & 1948 & 1948 \\
$R^{2}$ & 0.112 & - & - \\
\hline
\end{tabular}

Notes: IV regression, "Rest of Region" output gap as instrument; all regressions with country-fixed effects; robust standard errors in parentheses. Sample limited to countries with at least 1 million inhabitants (average over the sample) and more than 15 data points.

Controls: TOT_Gap, GovCons $(t-1)$; Columns (2) (resp. (3)) also Democ, Control_Corruption $\times$ Democ, and Output_Gap $\times$ Democ (resp. Polity2, Control_Corruption $\times$ Polity2, and Output_Gap $\times$ Polity2).

${ }^{*}$ Significant at $10 \% ;{ }^{* *}$ significant at $5 \% ;{ }^{* * *}$ significant at $1 \%$.

more countercyclical fiscal policy. ${ }^{18}$ This confirms that procyclical fiscal policy is more prevalent in the more corrupt countries. The coefficients suggest that a country with the mean level of corruption (normalized to zero in the KKM scale) displays slightly countercyclical fiscal policy - though the coefficient is not significantly different from zero-and worsening corruption by one standard deviation (normalized to one) is enough to invert that picture. In column 2 we control for the role of democracy: Corruption has an effect on procyclicality only in democracies, in accordance with the political agency model. In other words, it is the interaction of democratic accountability and corruption that leads to procyclicality, not corruption per se (nor democracy per se). These results are robust to alternative specifications of the democracy variable. When we used the continuous variable Polity 2 to measure democracy, we have no changes in the results, as shown in column 3 of this table. We also considered the fact that Control_of_Corruption is positively correlated with GDP per capita. We controlled for this variable (GDP per capita) entered alone and as an interaction with the output gap, but our results are qualitatively and quantitatively unchanged.

In Table 4 we repeat the same regression for government consumption. The most important coefficient for our purposes is the one on the two variables measuring democracy. The negative sign of these coefficients (which are statistically significant at the 5\% level) implies that spending is more countercyclical if there

18. Note that the variable Control_of_Corruption alone could not be included because of collinearity with the country fixed effects. 
is a better control of corruption, but this effect is only present under democracies. This effect of the interaction between control of corruption and democracy is in line with the predictions of the model, and consistent with the results in Table 3 on the fiscal surplus.

\subsection{Borrowing Constraints}

The major alternative explanation of a procyclical fiscal policy, different from our own, is that of borrowing constraints. How can we discriminate between these two explanations, corruption vs. borrowing constraints?

The key difficulty in addressing this issue is that corruption and credit ratings are very highly correlated. The correlation coefficient between the variables $S \& P$ Rating and Control_of_Corruption is 0.90. Control_of_Corruption is also highly correlated with available data on interest rate spreads (Spread), a correlation of -0.70 . In fact, these variables are correlated by construction. For instance Standard and Poor's may look (directly or indirectly) to perception of corruption as one of their inputs in assigning ratings to countries, and perceptions of corruption may in turn be influenced by foreigners' views of a country's credit-worthiness. As a result, it is very hard to disentangle the effects of one versus the other. When one or the other of the variables $S \& P$ Rating and Spread is added to the specification of Tables 2 and 3, both alone and as interactions with the output gap, the results are inconclusive; generally speaking, both variables of interest (corruption and credit constraints) are insignificant.

Thus, we have to discriminate between our corruption hypothesis and a simple credit rationing explanation of procyclicality in other ways. A first observation relates to the results on the interaction between democracy and corruption. As illustrated in the previous section, the correlation between corruption and procyclicality is stronger in democracies. This is a direct implication of our model. To be also consistent with a borrowing constraint story, corrupt democracies would have to be worse borrowers than corrupt dictatorships (whereas less corrupt governments would be equally trustworthy in democracies and autocracies). A priori one can think of many reasons why it might be the opposite, or at least why the interaction between democracy and corruption would not be relevant in determining credit worthiness.

Table 5 presents a second bit of evidence not fully consistent with a simple credit rationing explanation of procyclicality. Here we repeat the same regressions of Table 1, with the budget surplus as a dependent variable, but we estimate it for two subsamples: pre- and post-1982, the year of the Mexican debt crises that opened up two decades of debt crises, defaults, and so forth. Sovereign borrowers were much more likely to be up against a binding credit ceiling after 1982 than before, as concerns about default and credit-worthiness became an issue mainly 
TABLE 5. Cyclicality of fiscal policy: OECD versus non-OECD, pre- and post-1982 (dependent variable: $\Delta$ CGSurplus).

\begin{tabular}{|c|c|c|c|c|c|c|c|c|}
\hline & \multicolumn{4}{|c|}{ Pre-1982 } & \multicolumn{4}{|c|}{ Post-1982 } \\
\hline & \multicolumn{2}{|c|}{ OECD sample } & \multicolumn{2}{|c|}{ Non-OECD sample } & \multicolumn{2}{|c|}{ OECD sample } & \multicolumn{2}{|c|}{ Non-OECD sample } \\
\hline & $(1)$ & (2) & (3) & (4) & (5) & (6) & (7) & $(8)$ \\
\hline Output_Gap & $\begin{array}{c}0.882 \\
(0.254)^{* * *}\end{array}$ & $\begin{array}{c}0.259 \\
(0.255)\end{array}$ & $\begin{array}{l}-0.171 \\
(0.278)\end{array}$ & $\begin{array}{l}-0.298 \\
(0.235)\end{array}$ & $\begin{array}{c}0.684 \\
(0.249)^{* * *}\end{array}$ & $\begin{array}{c}0.887 \\
(0.249)\end{array}$ & $\begin{array}{c}0.084 \\
(0.186)\end{array}$ & $\begin{array}{r}0.245 \\
(0.196)\end{array}$ \\
\hline Country FE & No & Yes & No & Yes & No & Yes & No & Yes \\
\hline $\begin{array}{l}\text { Observations } \\
R^{2}\end{array}$ & 147 & $\begin{array}{c}147 \\
0.423\end{array}$ & $\begin{array}{c}268 \\
0.127\end{array}$ & $\begin{array}{c}268 \\
0.432\end{array}$ & $\begin{array}{c}381 \\
0.118\end{array}$ & $\begin{array}{c}381 \\
0.141\end{array}$ & $\begin{array}{c}931 \\
0.187\end{array}$ & $\begin{array}{c}931 \\
0.234\end{array}$ \\
\hline
\end{tabular}

Notes: IV regression, "Rest of Region" output gap as instrument; robust standard errors in parentheses. Sample limited to countries with at least 1 million inhabitants (average over the sample) and more than 15 data points.

Controls: TOT_Gap, CGSurplus $(t-1)$.

${ }^{*}$ Significant at $10 \% ;{ }^{* *}$ significant at $5 \% ;{ }^{* * *}$ significant at $1 \%$.

after the Mexican debt crisis. Yet, as shown in Table 5, there is no evidence that procyclicality increased after 1982. Developed countries display countercyclical fiscal policy (a positive estimated $\beta$ coefficient) both before and after 1982. In developing countries, the estimated $\beta$ coefficient is insignificantly different from zero in both samples. Note that in the post-1982 sample at least the coefficient on developing countries has the "right" sign, namely, the sign consistent with countercyclicality, whereas in the pre-1982 sample it has the sign consistent with procyclicality. The procyclicality of fiscal policy in developing countries is not driven by post-1982 observations. If anything, the reverse seems true.

In Table 6 we report yet another indirect test. Here we estimate the response of the budget surplus to downturns (negative output gap) and upturns (positive output gap) separately. As discussed in Section 2, borrowing constraints can only bind the socially optimal policy in downturns; hence, if procyclicality is driven by a debt limit, it should be particularly pronounced with a negative income shock. In an upturn, a benevolent government aware of its future borrowing constraints should save rather than overspend. Hence, under a debt limit we should observe a negative $\beta$ coefficient (procyclical policy) in a recession, but not in a boom. This is exactly the opposite of what we find in developing countries. Columns 1 and 2 of Table 6 refer to OECD countries (with and without country effects); columns 3 and 4 refer to non-OECD countries. One result is especially striking: In developing countries the procyclicality (negative $\beta$ ) of fiscal policy is entirely driven by the upturns. That is, the surplus falls (in percent of GDP) when the output gap goes up. During recessions, instead, the budget surplus in percent of GDP does not significantly respond to the output gap, meaning that non-OECD countries are able to run larger deficits in a recession. This seems inconsistent with a theory that relies on borrowing constraints. 
TABLE 6. Cyclicality of fiscal policy: OECD versus non-OECD in booms and recessions (dependent variable: $\triangle$ CGSurplus).

\begin{tabular}{lccccc}
\hline & \multicolumn{2}{c}{ OECD sample } & & \multicolumn{2}{c}{ Non-OECD sample } \\
\cline { 2 - 3 } \cline { 6 - 6 } & $(1)$ & $(2)$ & & $(3)$ & $(4)$ \\
\hline Output_Gap $\times$ Recession & 1.064 & 0.975 & & 0.194 & 0.368 \\
& $(0.421)^{* *}$ & $(0.370)^{* * *}$ & & $(0.309)$ & $(0.309)$ \\
Output_Gap $\times$ Boom & -0.093 & 0.105 & & -0.357 & -0.411 \\
& $(0.358)$ & $(0.356)$ & & $(0.384)$ & $(0.425)$ \\
Country FE & No & Yes & & No & Yes \\
Observations & 528 & 528 & & 1199 & 1199 \\
$R^{2}$ & 0.133 & 0.174 & & 0.16 & 0.217 \\
\hline
\end{tabular}

Notes: IV regression, "Rest of Region" output gap as instrument; robust standard errors in parentheses. Sample limited to countries with at least 1 million inhabitants (average over the sample) and more than 15 data points.

Controls: TOT_Gap, CGSurplus $(t-1)$.

${ }^{*}$ Significant at $10 \% ;{ }^{* *}$ significant at $5 \% ;{ }^{* * *}$ significant at $1 \%$.

Summarizing, there is nothing in the data that points to the superiority of the borrowing constraint hypothesis over our theory of political constraints and imperfect control of government. If anything, the evidence reported in this section is hard to reconcile with the borrowing constraint approach.

\subsection{Sensitivity Analysis}

Finally, we perform several robustness checks.

Different procedures for testing degree of procyclicality. Estimating the cyclical response of fiscal policy in a large panel of heterogeneous countries, as done in the previous tables, constraints some slope coefficients to be the same in all countries. This increase in efficiency of the estimates may come at the expense of specification bias. To assess the robustness of the results, here we estimate the effect of corruption on procyclicality in a two-step procedure.

First, we estimate the $\beta$ coefficients in equation (15) separately for each country. The estimated $\beta$ coefficients vary considerably across countries, and generally indicate more procyclical fiscal policy in developing countries, particularly in Latin America and in Sub-Saharan Africa. This is consistent with the results reported in Table 1.

Then we run a cross-country regressions of the following type:

$$
\text { Beta }_{i}=\varphi_{0}+\varphi_{1} \text { Control_of_corruption }{ }_{i}+\varphi_{2} X_{i}+u_{i},
$$

where the $i$ subscript denotes countries and $X$ is a vector of controls that includes per capita income measured the year before the start of the sample, and the 
TABLE 7. Cross-country regressions: Cyclicality of budget surplus (dependent variable: Beta of budget surplus).

\begin{tabular}{lcccccc}
\hline & $(1)$ & $(2)$ & $(3)$ & $(4)$ & $(5)$ & $(6)$ \\
\hline Control of Corruption & 0.162 & 0.172 & 0.185 & 0.074 & 0.167 & 0.141 \\
& $(0.048)^{* * *}$ & $(0.076)^{* *}$ & $(0.082)^{* *}$ & $(0.199)$ & $(0.088)^{*}$ & $(0.121)$ \\
Initial GDP (per capita) & & -0.016 & 0.012 & 0.003 & -0.013 & -0.018 \\
& & $(0.090)$ & $(0.089)$ & $(0.094)$ & $(0.093)$ & $(0.100)$ \\
Democracy & & & -0.164 & -0.082 & & \\
& & $(0.151)$ & $(0.194)$ & & \\
Democracy $\times$ Control of & & & 0.12 & & \\
$\quad$ Corruption & & & $(0.224)$ & & \\
Polity2 & & & & & 0.001 & 0.002 \\
Polity2 $\times$ Control of & & & & & & $0.016)$ \\
$\quad$ Corruption & & & & & & 0.003 \\
Observations & & & & & & \\
$R^{2}$ & 0.08 & 0.08 & 0.089 & 0.09 & 0.08 & $0.013)$ \\
\hline
\end{tabular}

Notes: Weighted Least Squares regression (weight = inverse of standard deviation of Beta), Beta computed using "Rest of Region" output gap as instrument. Robust standard errors in parentheses. Sample limited to countries with at least 1 million inhabitants (average over the sample) and more than 15 data points.

${ }^{*}$ Significant at $10 \% ;{ }^{* *}$ significant at $5 \% ;{ }^{* * *}$ significant at $1 \%$.

other controls listed in the various tables. When fiscal policy refers to the budget surplus, a higher Beta means a more countercyclical fiscal policy, and vice versa for government spending. The coefficient of interest is $\varphi_{1}$, which we expect to be positive when Beta refers to the budget surplus, and negative when Beta refers to government spending: fiscal policy is more countercyclical when there is better control of corruption.

Table 7 illustrates the results. Here Beta is estimated from the budget surplus, hence a higher value of Beta means a more countercyclical fiscal policy. The sign of the coefficient on Control_of_Corruption is positive and significant, as expected (columns 1 and 2), even when we control for the level of GDP per capita. The interaction of this coefficient with the variable Democracy is however insignificant. Results do not change when we control for the size of government (measured by total government spending over GDP averaged over the relevant time period). Results on government consumption (available upon request) are similar; as for the surplus, we do not find a statistically significant effect of democracy even though the sign of the coefficient is correct.

The voracity effect. Our story based upon corruption and the interaction with elections can easily coexist with the voracity effect. To check that, we used the same variable used by Lane (2003), which captures the fragmentation of the political process. This is a variable, introduced by Henisz (2000), which measures 
TABLE 8. Pooled sample: Voracity, corruption, and the cyclicality of the budget surplus in democracies and non-democracies (dependent variable: $\Delta$ CGSurplus).

\begin{tabular}{|c|c|c|c|c|}
\hline & \multicolumn{2}{|c|}{ Democracies } & \multicolumn{2}{|c|}{ Full Sample } \\
\hline & (1) & (2) & (3) & (4) \\
\hline Output_Gap & $\begin{array}{c}-0.267 \\
(0.21)\end{array}$ & $\begin{array}{l}-1.250 \\
(1.043)\end{array}$ & $\begin{array}{l}-0.144 \\
(0.215)\end{array}$ & $\begin{array}{l}-0.158 \\
(0.231)\end{array}$ \\
\hline Fragmentation $\times$ Output_Gap & $\begin{array}{c}1.451 \\
(0.572)^{* *}\end{array}$ & $\begin{array}{l}3.470 \\
(2.206)\end{array}$ & & \\
\hline Control_Corruption $\times$ Output_Gap & & $\begin{array}{c}0.209 \\
(0.149)\end{array}$ & & \\
\hline Fragmentation $\times$ Output_Gap $\times$ Democ & & & $\begin{array}{c}3.910 \\
(2.329)^{*}\end{array}$ & $\begin{array}{l}3.606 \\
(2.297)\end{array}$ \\
\hline Fragmentation $\times$ Output_Gap $\times$ NonDemoc & & & $\begin{array}{l}-0.119 \\
(1.863)\end{array}$ & $\begin{array}{l}-0.156 \\
(1.894)\end{array}$ \\
\hline Control_Corruption $\times$ Output_Gap $\times$ Democ & & & & $\begin{array}{l}0.234 \\
(0.147)\end{array}$ \\
\hline Control_Corruption $\times$ Output_Gap $\times$ NonDemoc & & & & $\begin{array}{l}-0.046 \\
(0.172)\end{array}$ \\
\hline Observations & 1144 & 1144 & 1668 & 1668 \\
\hline$R^{2}$ & 0.099 & 0.099 & 0.133 & 0.140 \\
\hline
\end{tabular}

Notes: IV regression, "Rest of Region" output gap as instrument; all regressions with country fixed effects; robust standard errors in parentheses. Sample limited to countries with at least 1 million inhabitants (average over the sample) and more than 15 data points.

Controls: TOT_Gap, GovCons $(t-1)$; Columns (3) and (4) also Democ, Fragmentation $\times$ Democ, and Output_Gap $\times$ Democ, Column (4) also Control_Corruption $\times$ Democ.

${ }^{*}$ Significant at $10 \% ;{ }^{* *}$ significant at $5 \% ;{ }^{* * *}$ significant at $1 \%$.

on a $(0,1)$ scale the extent of checks and balances imposed by the number of veto points that are present in the executive and legislative branches - a higher value means more effective checks and balances. ${ }^{19}$ This variable has a correlation of about 0.5 with our measure of control of corruption, which is not surprising given that checks and balances may be designed precisely to keep governments responsive and less corrupt.

We run our regression using this variable, at first limiting the sample to democratic countries, where we can interpret checks and balances as a proxy for the voracity effect - in fact, a dictator can ignore formal constitutional rules, which tend to be almost meaningless in many autocracies. Column 1 in Table 8 shows that the variable turns out to be indeed significant. In this respect Lane's result obtained for OECD countries does generalize in a larger sample. But when we use both variables, corruption and the Henisz fragmentation variable (as seen in column 2), both have insignificant coefficients (although with the expected sign), due to their relatively high correlation. The same pattern shows up when

19. The variable is available for the years between 1960 and 2004, thereby covering our entire sample period. It is available at $<w w w-m a n a g e m e n t . w h a r t o n . u p e n n . e d u / h e n i s z>$. 
TABLE 9. Pooled sample: Other measures of corruption and the cyclicality of the budget surplus in democracies and non-democracies (dependent variable: $\Delta$ CGSurplus).

\begin{tabular}{lccccc}
\hline & \multicolumn{2}{c}{ Transparency } & & \multicolumn{2}{c}{ ICRG } \\
\cline { 2 - 3 } \cline { 5 - 6 } & $(1)$ & $(2)$ & & $(3)$ & $(4)$ \\
\hline Output_Gap & -0.452 & -0.436 & & -0.659 & -0.201 \\
& $(0.242)^{*}$ & $(0.300)$ & & $(0.331)^{* *}$ & $(0.508)$ \\
Control_Corruption $\times$ Output_Gap & 0.121 & & 0.238 \\
& $(0.040)^{* * *}$ & & $(0.088)^{* * *}$ & \\
Control_Corruption $\times$ Output_Gap $\times$ Democ & & 0.116 & & & 0.276 \\
& & $(0.062)^{*}$ & & & $(0.144)^{*}$ \\
Control_Corruption $\times$ Output_Gap $\times$ NonDemoc & & 0.054 & & 0.015 \\
& & $(0.050)$ & & $(0.199)$ \\
Observations & 1459 & 1424 & & 1650 & 1615 \\
$R^{2}$ & 0.219 & 0.199 & & 0.220 & 0.214 \\
\hline
\end{tabular}

Notes: IV regression, "Rest of Region" output gap as instrument; all regressions with country fixed effects; robust standard errors in parentheses. Sample limited to countries with at least 1 million inhabitants (average over the sample) and more than 15 data points.

Controls: TOT_Gap, CGSurplus $(t-1)$; Columns (2) and (4) also Democ, Control_Corruption $\times$ Democ, and Output_Gap $\times$ Democ.

${ }^{*}$ Significant at $10 \%$; ${ }^{* *}$ significant at $5 \% ;{ }^{* * *}$ significant at $1 \%$.

we consider the entire sample, but include the interaction with democracy, as in columns 3 and 4 . We interpret these results as suggestive that both channels, voracity and corruption, may be present; but given the correlation between the two measures, it is difficult to disentangle how much of the effect to attribute to one and the other.

Different measures of corruption. We repeated all our tests using data on corruption perceptions from ICRG (available from 1985 onward) and from Transparency International (available from 1996 onward). The results, which are summarized in Table 9, were very similar. This is not surprising, because these corruption indicators are highly correlated with each other and move slowly over time.

\section{Conclusions}

In many developing countries fiscal policy is procyclical. Our explanation is that rational voters do not trust corrupt governments with resources. When voters realize that a positive income shock has hit the economy, they demand immediate benefits in the form of tax cuts or increases in productive government spending or transfers. They fear that otherwise the available extra resources would be "wasted" in rents. Faced with these procyclical demands by voters, governments do not accumulate reserves in good times; on the contrary, they incur large debts. From the voters' point of view, this seemingly myopic policy is a second 
best: They give up on consumption-smoothing opportunities, but at least they avoid leaving excessive rents to corrupt governments. This political distortion, related to the "starve the Leviathan" argument, leads to excessive accumulation of government debt and procyclical fiscal policy. Credit constraints come into play indirectly because the political distortion may push the government towards levels of debt that are at the limit of what they can repay, and therefore at the limit of what borrowers can lend. Other explanations of procyclical fiscal policy have argued that the "malfunctioning" of credit markets makes it hard or impossible for developing countries to borrow exactly when they need it more, namely, in bad times. But this argument fails to explain why welfare-maximizing governments fail to take this into account, building up reserves in good times, so as to avoid being credit-constrained in bad times.

Our theoretical model suggests that this failure to self-insure stems from a political agency problem inside each country. The evidence supports this explanation. On the one hand, procyclicality of fiscal policy is more pronounced in countries where corrupt governments are held accountable by voters through democratic institutions. On the other hand, in developing countries procyclicality of fiscal policy is more often driven by a distorted policy reaction to booms, rather than to recessions. Although we have focused on this novel model and found empirical support for it, other sources of political failure may be present, in particular the voracity effect, which can coexist with our political agency distortion.

\section{Appendix}

PROPOSITION 2. Suppose that the upper bound on rents depends on debt outstanding, $q_{t}=Q\left(b_{t}\right)$. Then the equilibrium stochastic steady state has

$$
r^{*}=v^{-1}\left[v\left(Q\left(b^{*}\right)\right)(1-\beta)\right]
$$

and steady state debt is at an interior optimum $b^{*}<\bar{b}$. Public consumption and tax rates are still defined as in Proposition 1. Under mild regularity conditions, the steady state is locally stable. During the adjustment to the steady state, income shocks only affect public consumption and the tax rate, whereas rents and government debt are not affected by income shocks.

Proof. Now consider the case in which the upper bound on rents is a decreasing function of debt outstanding: $Q_{t}=Q\left(b_{t}\right)$, with $Q_{b}, Q_{b b}<0$. Going through the same steps as in Section 3, in equilibrium the government must be indifferent between pleasing the voters and being reappointed (taking into account the future equilibrium continuation value), or grabbing as many rents as possible today. 
This indifference condition (the analogue of equation (9) in Section 3) here can be written as

$$
v(r)+\beta v\left(Q\left(b^{\prime}\right)\right)=v(Q(b)) .
$$

Hence, equilibrium rents are determined jointly with equilibrium government debt. Repeating the steps of Section 3, a government seeking reappointment chooses public debt so as to maximize equation (11). But here, $E V\left(b^{\prime}, y^{\prime}\right)=$ $v\left(Q\left(b^{\prime}\right)\right)$. Hence, equilibrium public debt is determined by the following optimality condition:

$$
v_{r}(r)=-v_{r}\left(Q\left(b^{\prime}\right)\right) Q_{b}\left(b^{\prime}\right) .
$$

The left hand side of equation (A.2) is the marginal benefit of borrowing, namely the additional rents that the government can grab today with the debt proceeds. The right-hand side is the marginal cost of issuing debt, namely, the reduction in the upper bound of rents tomorrow, which in turn reduces the value of the incumbent's future out-of-equilibrium threat. Together, equations (9) and (A.2) determine the equilibrium time paths of rents and public debt.

The steady state is obtained imposing $b^{\prime}=b=b^{*}$ in (A.1), to yield an expression for equilibrium rents that closely resembles equation (10) in Section 3 :

$$
v\left(r^{*}\right)=v\left(Q\left(b^{*}\right)\right)(1-\beta) .
$$

By (A.3), equilibrium rents are below the upper bound in the steady state: $r^{*}<Q\left(b^{*}\right)$. With strictly concave preferences, equation (A.2) then implies that the steady state is at an interior optimum (i.e., $b^{*}<\bar{b}$ ) only if $Q_{b}\left(b^{*}\right)>1$. Intuitively, for the government to borrow less than the maximum $\bar{b}$, the cost of issuing government debt must be high enough. With $r^{*}<Q\left(b^{*}\right)$, the marginal utility of current rents is higher than the marginal utility of rents evaluated at the upper bound; hence the government finds it optimal not to issue more debt only if the upper bound on rents shrinks more than one for one as more debt is issued: $Q_{b}\left(b^{*}\right)>1$. Assuming that this condition holds for some $b<\bar{b}$, then the steady state can correspond to an interior optimum for government debt.

We now show that the steady state is locally stable (i.e., that $d b^{\prime} / d b<1$ in a neighborhood of the steady state). Equation (A.2) implicitly defines equilibrium rents as a function of government debt: $r=F\left(b^{\prime}\right)$. Applying the implicit function theorem to (A.2), we also have

$$
F_{b}\left(b^{\prime}\right)=\frac{v_{r r}\left(Q\left(b^{\prime}\right)\right) Q_{b b}\left(b^{\prime}\right)}{v_{r r}\left(F\left(b^{\prime}\right)\right)}<0 .
$$

Replacing $r=F\left(b^{\prime}\right)$ in equation (A.1), the equilibrium law of motion of government debt is implicitly defined by

$$
v\left[F\left(b^{\prime}\right)\right]+\beta v\left[Q\left(b^{\prime}\right)\right]-v[Q(b)]=0 .
$$


Now use equation (A.5) to compute $d b^{\prime} / d b$ in a neighborhood of the point $b^{\prime}=$ $b=b^{*}$. After some simplifications we have

$$
\frac{d b^{\prime}}{d b}=\frac{1}{\beta-F_{b}\left(b^{*}\right)}>0 .
$$

Thus, recalling that $F_{b}(b)<0$, that $F(b)<Q(b)$ and that $Q_{b b}<0$, and using equation (A.4), we have that $d b^{\prime} / d b<1$, provided that $v_{r r r} \geq 0$ and that $Q_{b b}$ is not too close to 0 in absolute value.

Finally, note that in equilibrium (on and off the steady state) neither rents nor public debt depend on income. The budget constraint then implies that temporary income shocks change consumption one for one.

\section{References}

Aiyagari, S. Rao (1994). "Uninsured Idiosyncratic Risk and Aggregate Saving." Quarterly Journal of Economics, 109, 659-684.

Alesina, Alberto, and Roberto Perotti (1995). "The Political Economy of Budget Deficits." IMF Staff Papers, 42, 1-31.

Alesina, Alberto, and Guido Tabellini (1990). "A Positive Theory of Fiscal Deficits and Government Debt." Review of Economic Studies, 57, 403-414.

Barro, Robert (1973). "The Control of Politicians: An Economic Model.” Public Choice, 13, $19-42$.

Cantor, Richard, and Frank Packer (1996). "Determinants and Impact of Sovereign Credit Ratings." Federal Reserve Bank of New York Economic Policy Review, 20, 37-54.

Catão, Luis A., and Bennett W. Sutton (2002). "Sovereign Defaults: The Role of Volatility." IMF Working Papers 02/149, International Monetary Fund.

Ferejohn, John (1986). "Incumbent Performance and Electoral Control.” Public Choice, 50, $5-25$.

Galí, Jordi, and Roberto Perotti (2003). "Fiscal Policy and Monetary Policy Integration in Europe.” Economic Policy, 37, 533-572.

Gavin, Michael, and Roberto Perotti (1997). "Fiscal Policy in Latin America." NBER Macroeconomics Annual 1997, edited by Ben Bernanke and Julio Rotemberg. MIT Press.

Henisz, Witold (2000). "The Institutional Environment for Economic Growth." Economics \& Politics, 12, 1-31.

Jaimovich, Dany, and Ugo Panizza (2007). "Procyclicality or Reverse Causality?" RES Working Papers 1029, Inter-American Development Bank.

Jensen, Michael C., and William H. Meckling (1976). "Theory of the Firm: Managerial Behavior, Agency Costs and Ownership Structure." Journal of Financial Economics, 3, 305-360.

Kaminski, Graciela, Carmen Reinhart, and Carlos Vegh (2004). "When It Rains It Pours: Procyclical Capital Flows and Macroeconomic Policies." NBER Macroeconomic Annual 2004, edited by Mark Gertler and Kenneth Rogoff. MIT Press.

Kaufman, Daniel, Aart Kraay, and Massimo Mastruzzi (2006). "Governance Matters V: Governance Indicators for 1996-2005.” World Bank Policy Research Working Paper 4012.

Lane, Philip (2003). "The Cyclical Behavior of Fiscal Policy: Evidence from the OECD." Journal of Public Economics, 87, 1661-1675.

Lane, Philip, and Aaron Tornell (1998). "Why Aren't Latin American Saving Rates Procyclical?” Journal of Development Economics, 57, 185-200. 
Ljungqvist, Lars, and Thomas J. Sargent (2000). Recursive Macroeconomic Theory. MIT Press.

Manasse, Paolo (2005). "Pro-Cyclical Fiscal Policy: Shocks, Rules and Institutions: A View from MARS.” IMF Working Papers 06/27, International Monetary Fund.

Milesi Ferretti, Gian Maria (2003). "Good Bad or Ugly? On the Effects of Fiscal Rules on Creative Accounting." Journal of Public Economics, 88, 377-394.

Perotti, Roberto (2004). "Estimating the Effects of Fiscal Policy in OECD Countries." Working paper, IGIER-Bocconi.

Persson, Torsten, and Lars Svensson (1989). "Why a Stubborn Conservative Would Run a Deficit: Policy with Time-Inconsistent Preferences." Quarterly Journal of Economics, 104, 325-345.

Persson, Torsten, and Guido Tabellini (2000). Political Economics: Explaining Economic Policy. MIT Press.

Polity IV Project. Available at $<$ www.cidcm.umd.edu/inscr/polity/\#data $>$.

Ravn, Morten O., and Harald Uhlig (2002). "On Adjusting the Hodrick-Prescott Filter for the Frequency of Observations." Review of Economics and Statistics, 84, 371-376.

Riascos, A., and C. Vegh (2003). "Procyclical Government Spending in Developing Countries: The Role of Capital Market Imperfections.” Working paper, University of Maryland.

Rogoff, Kenneth (1990). "Equilibrium Political Budget Cycles." American Economic Review, 80, 21-36.

Rogoff, Kenneth, and Ann Sibert (1988). "Elections and Macroeconomic Policy Cycles." Review of Economic Studies, 55, 1-16.

Satyanath, Shanker, and Arvind Subramanian (2004). "What Determines Long-Run Macroeconomic Stability? Democratic Institutions." IMF Working Paper 04/215, International Monetary Fund.

Standard and Poor's Credit Ratings. Available at <www2.standardandpoors.com $>$.

Tabellini, Guido, and Alberto Alesina (1990). "Voting on the Budget Deficit." American Economic Review, 80, 37-49.

Talvi, Ernesto, and Carlos Vegh (2005). "Tax Base Variability and Procyclicality of Fiscal Policy." Journal of Development Economics, 78, 156-190.

Tornell, Aaron, and Philip Lane (1999). "Voracity and Growth." American Economic Review, $89,22-46$.

Von Hagen, Jurgen, and Jan Harden (1994). "National Budget Process and Fiscal Performance." European Economy Reports and Studies, 3, 311-344. 
Copyright of Journal of the European Economic Association is the property of MIT Press and its content may not be copied or emailed to multiple sites or posted to a listserv without the copyright holder's express written permission. However, users may print, download, or email articles for individual use. 